Wei-Lung Tseng
Yang-Wei Lin

Ko-Chun Chen

Huan-Tsung Chang

Department of Chemistry, National Taiwan University, Taipei, Taiwan, R.O.C.

\section{DNA analysis on microfabricated electrophoretic devices with bubble cells}

\begin{abstract}
Microfluidic devices with bubble cells have been fabricated on poly(methyl methacrylate) (PMMA) plates and have been employed for the analysis of DNA using polyethylene oxide (PEO) solutions. First, the separation channel was fabricated using a wireimprinting method. Then, wires with greater sizes or a razor blade glued in a polycarbonate plate was used to fabricate bubble cells, with sizes of 190-650 $\mu \mathrm{m}$. The improvements in resolution and sensitivity have been achieved for large DNA ( > 603 base pair, bp) using such devices, which depend on the geometry of the bubble cell. The main contributor for optimal resolution is mainly due to DNA migration at lower electric field strengths inside the bubble cell. On the other hand, slight losses of resolution for small DNA fragments have been found mainly due to diffusion, supported by the loss of resolution when separating two small solutes. With a bubble cell of $75 \mu \mathrm{m}$ (width) $\times 500 \mu \mathrm{m}$ (depth), the sensitivity improvement up to 17-fold has been achieved for the $271 \mathrm{bp}$ fragment in the separation of $\Phi X-174 /$ Haell DNA restriction fragments. We have also found that a microfluidic device with a bubble cell of $360 \mu \mathrm{m} \times 360 \mu \mathrm{m}$ is appropriate for DNA analysis. Such a device has been used for separating DNA ranging from 8 to $2176 \mathrm{bp}$ and polymerase chain reaction (PCR) products amplified after 30 cycles, with rapidity and improvements in the sensitivity as well as resolution.
\end{abstract}

Keywords: Bubble cell / DNA separation / Microfluidic devices / Sensitivity improvement

\section{Introduction}

Although the human genome sequence had been reported in 2001 [1, 2], it will not end the demand for developing new techniques for DNA analysis. In order to interpret the function of DNA sequence on a genomic scale, much more information from any other organisms is required. For example, so-called single nucleotide polymorphorism (SNP) has gained increasing attention in this regard, especially information about sequence variations in humans [3]. To exploit the wealth of genetic information, the concept of micrototal analysis systems ( $\mu$-TAS) has been proposed. These include systems based on highly functional architectures for bioanalysis such as DNA array and protein chips $[4,5]$, as well as separations (so-called lab-on-a-chip) [6-8]. Although the former provides a vast of information in one run cycle based on specific interactions, difficulty for making such a highly functional architecture, a needs to know certain information in advance,

Correspondence: Dr. Huan-Tsung Chang, Department of Chemistry, National Taiwan University, Taipei, Taiwan, R. O. C. E-mail: changht@ccms.ntu.edu.tw Fax: $+886-2-23621963$

Abbreviations: $\mathrm{EtBr}$, ethidium bromide; PC, polycarbonate; PEO, poly(ethylene oxide); PMMA, poly(methyl methacrylate); TB, Tris-borate and suffering from a highly reading-error rate are problems [4]. Owing to its simplicity and high resolving power, the latter, especially one with electrokinetic driving forces, has gained more attraction in analytical science $[9,10]$.

The advantages of microfluidic electrophoretic devices over slab gels for DNA separation and sequencing include rapidity, capability of the production of high-density microchannels, significant reduction of reagent used, and integration of sequencing functions. Such devices are commonly fabricated in glass, quartz, and polymer substrates [11-17]. Although the chemistry of the first two is well understood and they are optical transparent to visible lights, a more sophisticated photolithography process is generally needed. For this reason, it is not as attractive as polymer substrates, such as polycarbonate (PC) $[14,15]$, and PMMA [16, 17], that are easily fabricated by printing, laser ablation, and plasma etching and have a greater potential to make disposable devices on a cost-effective basis. From a practical point of view, methods or devices allowing hand-free, quick, and simple chemical and biochemical analysis are also essential. Currently, several excellent new systems allowing the performance of PCR and analysis of the products on chips have been developed, with advantages of rapidity and high throughput [18-20]. Despite these very promising developments, the properties of the supported material, 
injection, fluid handling, sensitivity, resolution, and overall cost still somehow limit a wider distribution of these devices in an academic and industrial environment. For example, owing to an extremely small injection volume $(\mathrm{pL})$ and a short optical length, the sensitivity and reproducibility are not excellent. Thus, more sophisticated injection and detection systems, greater amounts of DNA templates, and/or more PCR cycles are generally needed when compared to capillary electrophoresis (CE) that is currently more popular for DNA separations. It is also difficult to achieve single-base resolution and long read lengths of DNA sequences by using microfluidic devices [21, 22].

To make microfluidic electrophoretic devices more attractive for the analysis of DNA, the sensitivity and efficiency are two most important issues. The use of suitable polymer solutions and coated microchannel is essential to achieve high resolving power [23-27]. To minimize band broadening that causes the loss of resolution and to improve quantitative reproducibility, new injection schemes have been demonstrated [28, 29]. Because of a short separation length, the analysis of DNA is somehow limited, which has been partially overcome by the use of turns of microchannels fabricated on small chips [30-32]. However, turns noticeably degrade the band shape and overall separation efficiency and a more sophisticated technique is required to incorporate turns in channels to facilitate wafer-scale integration. Regarding sensitivity, the development of new detection systems based on laser-induced fluorescence in conjunction with the use of intercalators with high quantum yields has been demonstrated effective [33-35]. To further improve the sensitivity, on-line membrane concentration has been applied, with a 70-fold improvement in the sensitivity for the $199 \mathrm{bp}$ PCR product [36]. A large cross injector has been employed for increasing the injection volume, resulting in 5 to 10 -fold improvements in sensitivity [37, 38]. Besides, an integrated electrochemical detection system has been developed and tested with success for the analysis of PCR products [39].

In this report, we conducted DNA separations on microfabricated CE channels with bubble cells made by printing methods. With increasing the optical length, bubble cells have been demonstrated in improving sensitivity up to several tens-fold for the analysis of small solutes in CE [40-42]. One drawback of the use of bubble cells stems from the dispersion of electric field strengths and path length differences between molecules traveling along the central and outer parts, leading to loss of efficiency. The loss of efficiency is profound as the size of bubble cells increases. Another reason for making a limited size of the bubble cell comes from the size of a capillary. As a result, the improvement in the sensitivity is limited. As the geometry of the separation system affects the distribution of the electric field, thereby varying the electrophorteic mobility of DNA [43], it should have significant impacts on the resolution and sensitivity for DNA separations. To explore these impacts, the separation of DNA was conducted on plastic microfluidic devices with bubble cells of various sizes.

\section{Materials and methods}

\subsection{Equipment}

The basic design of the separation system is similar to Simpson's design [44]. Briefly, a high-voltage power supply from Bertan (Hicksville, NY, USA) was used to drive electrophoresis. The entire detection system was enclosed in a black box with a high-voltage interlock and the high-voltage end of the separation system was put in a laboratory-made plexiglass box for safety. A $4.0 \mathrm{~mW}$ He-Ne laser with $543.6 \mathrm{~nm}$ output from Uniphase (Mantence, CA, USA) was used for excitation. The light was collected with a $20 \times$ objective (numerical aperture $=0.25$ ). One RG 610 cutoff filter was used to block scattered light before the emitted light reached the photomultiplier tube (Hamamatsu R928). The amplified currents were transferred directly through a $10 \mathrm{k} \Omega$ resistor to a 24 bit A/D interface at $10 \mathrm{~Hz}$ (Borwin, JMBS Developments, Le Fontanil, France) and stored in a personal computer.

\subsection{Chemicals}

Wires $(75 \mu \mathrm{m}, 190$ and $360 \mu \mathrm{m}$ in diameter) used to fabricate microchannels and bubble cells were obtained from Omega (Stanford, CT, USA). Sulforhodamine B (SRB), Sulforhodamine 101 (SR101), all chemicals used for preparing buffer solutions, PEO $\left(M_{\mathrm{r}}=8000000\right)$, and polyvinylpyrrolidone $\left(M_{r}=1300000\right)$ were purchased from Aldrich (Milwaukee, WI, USA). Ethidium bromide (EtBr) was obtained from Molecular Probes (Eugene, OR, USA). TB buffer containing $200 \mathrm{~mm}$ tris(hydroxymethyl)aminomethane (Tris) was adjusted with boric acid to pH 9.0. ФX 174 RF DNA-Haelll digest was purchased from Pharmacia Biotech (Uppsala, Sweden). DNA markers V (pBR 322/Haelll digest) and VI (pBR 328/Bg1l digest \& pBR 328/Hinfl digest) were purchased from Boehringer Mannheim GmbH (Mannheim, Germany). Equal volumes of DNA markers $\mathrm{V}$ and $\mathrm{VI}$ were mixed and used in this study. 


\subsection{Preparation of PEO solutions}

Certain amounts of PEO were gradually added into $200 \mathrm{~mm}$ TB buffer, $\mathrm{pH}$ 9.0, in a beaker stirring in a water bath at 85 to $90^{\circ} \mathrm{C}$. During the addition of PEO, a magnetic stirring rod was used to produce a well homogeneous suspension. After addition was complete, the suspension was stirred for at least one more hour. Finally, polymer solutions were degassed with a vacuum system in an ultrasonic tank. Polymer solutions stored in a refrigerator at $4^{\circ} \mathrm{C}$ were usable for at least three days.

\subsection{DNA extraction and PCR products}

The blood sample was from a normal male. Human genomic DNA from buffy coat was extracted using the QIAamp DNA blood mini kit in accordance with manufacturer's instructions. Amplification of the DNA sample was conducted as suggested by the manufacturers. Briefly, $22.5 \mu \mathrm{L}$ PCR master mix component was prepared by mixing $17.45 \mu \mathrm{L}$ sterile water, $2.50 \mu \mathrm{L}$ STR $10 \times$ buffer, $0.05 \mu \mathrm{L}$ Taq polymerase $(5 \mathrm{u} / \mu \mathrm{L})$, and $2.50 \mu \mathrm{L}$ TH01 $10 \times$ primer pairs (5'-GTGGGCTGAAAAGCTCCCGATTAT-3' and 5'-ATTCAAAGGGTATCTGGGCTCTGG-3'). To the PCR master mix, $2.5 \mu \mathrm{L}$ of human genomic DNA (25 ng) was added. PCR was conducted as: initial incubation at $96^{\circ} \mathrm{C}$ for $2 \mathrm{~min}$, cycling for first 10 cycles at $94^{\circ} \mathrm{C}$ for $1 \mathrm{~min}$, at $64^{\circ} \mathrm{C}$ for $1 \mathrm{~min}$, and at $70^{\circ} \mathrm{C}$ for $1.5 \mathrm{~min}$, and cycling for the last 20 cycles, respectively, at $90^{\circ} \mathrm{C}$ for $1 \mathrm{~min}$, at $64^{\circ} \mathrm{C}$ for $1 \mathrm{~min}$, and at $70^{\circ} \mathrm{C}$ for $1.5 \mathrm{~min}$.

\subsection{Microfabrication}

A wire imprinting method was used to fabricate the separation microchannels with bubble cells [45]. First, a $75 \mu \mathrm{m}$ wire and a PMMA plastic plate clamped between two clean glass slides (the left side of Fig. $1 \mathrm{~A}$ ) was placed in the oven for $10 \mathrm{~min}$ at $110^{\circ} \mathrm{C}$. Then, the assembly was set at room temperature and thus the microchannel was formed. Next, a different size of wire $(0.5 \mathrm{~cm}$ with $360 \mu \mathrm{m})$ put on the top of the $75 \mu \mathrm{m}$ microchannel was clamped between two clean glass slides (the right side of Fig. 1A) and placed in the oven for $5 \mathrm{~min}$ at $110^{\circ} \mathrm{C}$. Prior to sealing, two holes of $3 \mathrm{~mm}$ in diameter used as buffer reservoirs and a hole of $0.8 \mathrm{~mm}$ in diameter used to allow injection were drilled. Two pieces of PMMA plastics were sealed in the oven for $10 \mathrm{~min}$ at $110^{\circ} \mathrm{C}$. A representative fabricated microchannel with a bubble cell is shown in Fig. 1B. Similarly, the microfabrication of a bubble cell with a similar width to that of the microchannel was performed using a PC plate that was put between a PMMA plastic plate and a glass side (Fig. 1C). To make a bubble cell with a depth of $500 \mu \mathrm{m}$, a razor blade was glued to the PC plate and
(A)

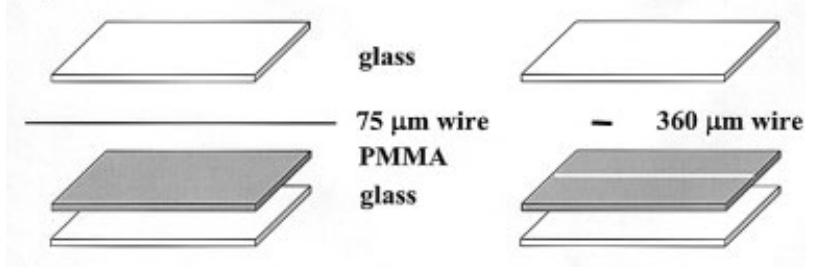

(B)

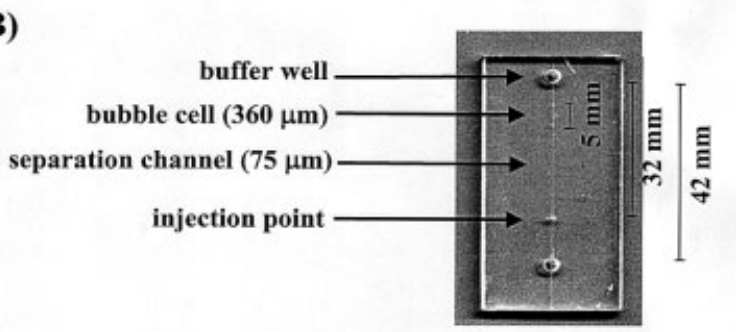

(C)

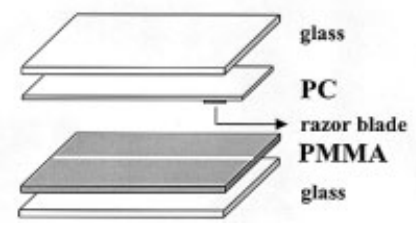

Figure 1. Microfabrication process of bubble cells using imprinted techniques. (A) Microfabrication of a microchannel of $75 \mu \mathrm{m} \times 75 \mu \mathrm{m}$ with a bubble cell of $360 \mu \mathrm{m} \times 360 \mu \mathrm{m}$ and (B) the product. (C) Assembly for making a bubble cell of $75 \mu \mathrm{m} \times 500 \mu \mathrm{m}$.

has an open part of $500 \mu \mathrm{m}$ above the PC surface. The polycarbonate chosen was due to its high softening temperature $\left(150^{\circ} \mathrm{C}\right)$. In order to reduce the variation of electroosmotic flow (EOF) and the interaction with DNA, the microchannels were coated with $5 \%$ polyvinylpyrrolidone at room temperature for $5 \mathrm{~min}$.

\subsection{Separation}

Filling the microchannel with PEO solution was conducted by pressure injection. Hydrodynamic injection of the DNA samples with concentrations ranging from 0.1 to $30 \mu \mathrm{g} / \mathrm{mL}$ was conducted by dipping a $30 \mathrm{~cm}$ capillary of $50 \mu \mathrm{m}$ ID at $10 \mathrm{~cm}$ height for $5 \mathrm{~s}$. With such a small capillary, the reproducibility of the fluorescence intensity for the $603 \mathrm{bp}$ fragment was less than $3.0 \%$ in five consecutive runs. After the injection, the open part of the injection point was covered with a piece of tape (Scotch type 810, 3M) in order to prevent the formation of bubbles. The separation was conducted at 255,750 or 1500 V. After each run, PEO solution was pushed out by pressure means and the microchannel was refilled with fresh PEO solution. 


\section{Results and discussion}

\subsection{Impact of bubble cells on DNA separation}

The electropherograms depicted in Figs. 2A-C clearly show increases in the sensitivity in the presence of a bubble cell, simply due to the increase in the optical length. In addition, at the same applied voltage (Figs. $2 \mathrm{~A}$ and $\mathrm{B}$ ) the resolution between any two DNA fragments larger than $603 \mathrm{bp}$ increased in the presence of the bubble cell, but at the expense of a longer separation time. The changes in the migration time were greater for the large DNA fragments, especially those larger than $603 \mathrm{bp}$, than for small ones. We inferred that these were due to the impact of electric field strength on the electrophoretic mobility of DNA, depending on the sizes of the separation channel and the bubble cell according to Eq. (1) [41]:

$E_{1} / E_{2}=K\left(r_{2}{ }^{2} / r_{1}{ }^{2}\right)$

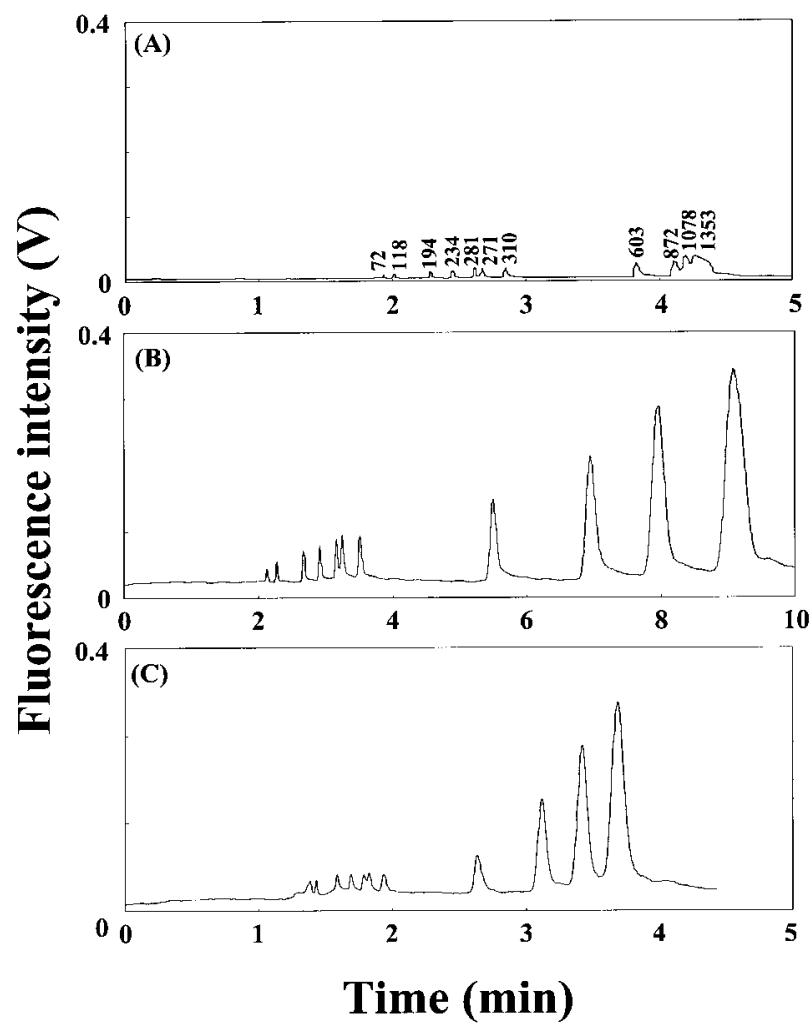

Figure 2. Separations of $30 \mu \mathrm{g} / \mathrm{mL} \Phi \times 174$ RF DNA-Haell digest in the absence or presence of a bubble cell using $1.5 \%$ PEO prepared in $200 \mathrm{~mm}$ TB containing $10 \mu \mathrm{g} / \mathrm{mL}$ $\mathrm{EtBr}, \mathrm{pH}$ 9.0. The separations were conducted at $(\mathrm{A}),(\mathrm{B})$ 750 V, and (C) 1500 V. (A) No bubble cell; (B), (C) with bubble cell of $360 \mu \mathrm{m} \times 360 \mu \mathrm{m}$. Length of the microchannel, $4.2 \mathrm{~cm}$; effective length of the microchannel, $2.4 \mathrm{~cm}$ (near the middle of the bubble cell if present); length of the bubble cell, $0.5 \mathrm{~cm}$. Hydrodynamic injections were conducted by dipping the DNA sample with a capillary of $50 \mu \mathrm{m}$ ID. where $E_{1}, E_{2}, r_{2}$, and $r_{1}$ represent the electric field strength and the radius of the separation channel and the bubble cell, respectively. It is important to note that Eq. (1) could not precisely express the distribution of the electric field strength inside the system, especially when the depth and width of the bubble cell are different. However, it does simply show the decrease in the electric field strength with increasing the size of the channel. As a result, DNA slowed down when entering the bubble cell, leading to a long migration time. Because the limited separation size, revealed by a large comigration peak of fragments larger than this limit in the electropherogram, decreases with increasing electric fields, resolution between any two adjacent large DNA fragments increased in the presence of the bubble cell. Figure $2 \mathrm{C}$ shows that the resolution was better for the large DNA pairs, with a shorter separation time, when compared to that shown in Fig. 2A. The results suggest that the resolution (except that for small DNA pairs) and sensitivity can be optimized at a shorter time when conducting DNA analysis at higher applied voltages in the presence of bubble cells.

\subsection{Effect of microchannel geometry}

To further explore the impact of electric field strength on DNA separation, we performed the DNA separations in the presence of bubble cells with different widths and depths, ranging from 190 to $650 \mu \mathrm{m}$ at the same applied voltages. Table 1 clearly shows that the resolution between any two DNA fragments smaller than $603 \mathrm{bp}$ decreased, while that for any adjacent large DNA pairs increased in the presence of the bubble cell (width and depth both $<360 \mu \mathrm{m}$ ). The changes in the resolution and migration time increased with increasing the size of the bubble cell, supporting our suggestion addressed above. Because electric field has a less effect on small DNA fragments [46], it is obvious that the loss of resolution was mainly due to diffusion, supported by the decrease in resolution with increases in the size of the bubble cell. When using a microfluidic device with a cell of $650 \mu \mathrm{m} \times 650 \mu \mathrm{m}$, the resolution lost mainly due to diffusion and the two large DNA fragments (1078 and $1353 \mathrm{bp}$ ) were not detected in the time course of the separation because the electric field strength inside the bubble cell was extremely low. For comparison, the results obtained from the separations at different applied voltages were also listed in Table 1. At $255 \mathrm{~V}$, the large DNA fragments were resolved without a bubble cell at the expense of a long separation time, supporting the impact of the electric field on DNA migration. It is important to note that all the DNA fragments were resolved in $4 \mathrm{~min}$ at $1500 \mathrm{~V}$ when using a bubble cell of $360 \mu \mathrm{m} \times 360 \mu \mathrm{m}$. To further show the feature of this device, we performed the separation of 
Table 1. Effect of width and depth of bubble cells on resolution

\begin{tabular}{|c|c|c|c|c|c|c|c|}
\hline \multirow[t]{2}{*}{ Base pairs } & \multicolumn{7}{|c|}{$\begin{array}{l}\text { Resolution } \\
\text { Width }(\mu \mathrm{m}) \times \text { depth }(\mu \mathrm{m})\end{array}$} \\
\hline & $75 \times 75^{\mathrm{a})}$ & $75 \times 75^{b)}$ & $75 \times 500^{\text {a) }}$ & $190 \times 190^{a)}$ & $360 \times 360^{\text {a) }}$ & $650 \times 650^{a)}$ & $360 \times 360^{c)}$ \\
\hline $72 / 118$ & 2.8 & 4.4 & 1.4 & 2.1 & 2.2 & 0.6 & 1.7 \\
\hline 118 / 194 & 8.1 & 8.7 & 8.7 & 7.1 & 5.9 & 1.5 & 3.0 \\
\hline $194 / 234$ & 4.9 & 4.4 & 5.0 & 3.5 & 3.3 & 0.9 & 1.9 \\
\hline 234 / 281 & 4.2 & 3.1 & 4.4 & 3.3 & 3.1 & 0.4 & 1.8 \\
\hline $281 / 271$ & 1.2 & 0.9 & 1.4 & 1.3 & 1.0 & 0 & 0.5 \\
\hline $271 / 310$ & 3.1 & 2.2 & 3.8 & 3.0 & 2.8 & 0.4 & 1.7 \\
\hline $310 / 603$ & 14.3 & 10.0 & 11.6 & 10.4 & 13.5 & 3.1 & 8.2 \\
\hline $603 / 872$ & 3.0 & 4.9 & 5.2 & 2.8 & 6.1 & 2.1 & 4.2 \\
\hline 872 / 1078 & 0.8 & 2.1 & 2.0 & 1.1 & 3.2 & - & 2.2 \\
\hline 1078 / 1353 & 0.4 & 1.2 & 1.0 & 0.6 & 2.6 & - & 1.6 \\
\hline S.W. (min) $)^{d)}$ & $1.93 \sim 4.27$ & $2.90 \sim 13.02$ & $2.63 \sim 10.50$ & $2.02 \sim 5.80$ & $2.13 \sim 9.09$ & $5.96 \sim 33.61^{\mathrm{e})}$ & $1.30 \sim 3.69$ \\
\hline
\end{tabular}

a) Applied voltage, $750 \mathrm{~V}$

b) Applied voltage, $255 \mathrm{~V}$

c) Applied voltage, $1500 \mathrm{~V}$

d) Separation window is between the migration time for $72 \mathrm{bp}$ and $1353 \mathrm{bp}$.

e) The last peak is $872 \mathrm{bp}$.

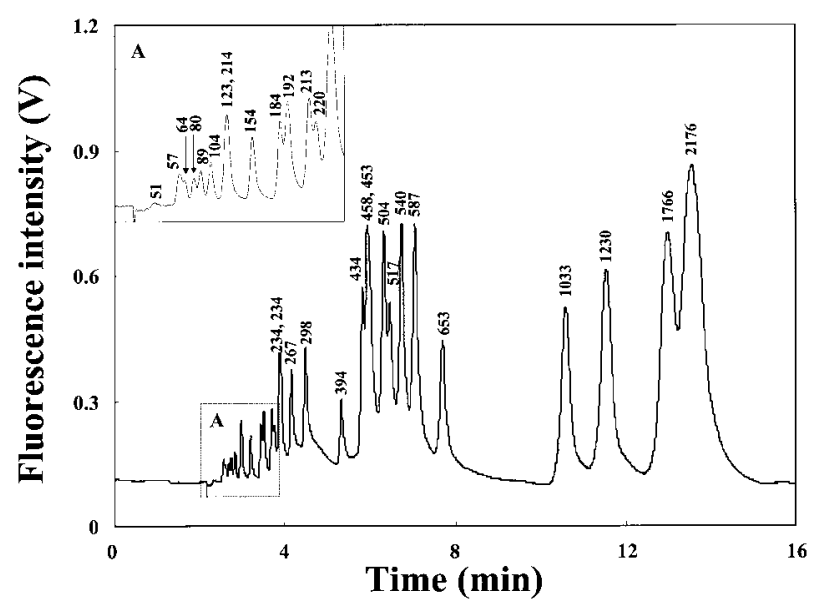

Figure 3. Separation of a sample containing $25 \mu \mathrm{g} / \mathrm{mL}$ DNA markers $\mathrm{V}$ and $\mathrm{VI}$ in the presence of a bubble cell of $360 \mu \mathrm{m} \times 360 \mu \mathrm{m}$ using 2.0\% PEO prepared in $200 \mathrm{~mm}$ TB containing $10 \mu \mathrm{g} / \mathrm{mL} \mathrm{EtBr}, \mathrm{pH}$ 9.0. Other conditions were as in Fig. 2.

the sample containing DNA markers V and VI. Figure 3 shows that the separation was complete in $15 \mathrm{~min}$, with the efficiency up to $5.1 \times 10^{5}$ plates/m (394 bp fragment). Compared to the result shown in our previous studies in CE [47-49], the resolution result is not impressed. This is likely due to a shorter separation length and DNA not migrating against EOF.

Next, we compared the resolution results obtained at different detection points, before $(2.1 \mathrm{~cm}$ from the injection point) and inside ( 2.3 and $2.6 \mathrm{~cm}$ from the injection point)

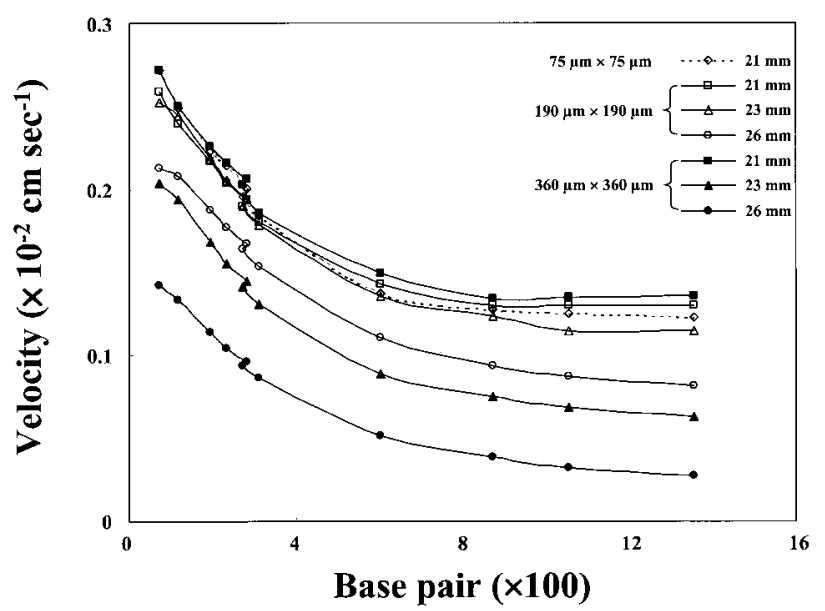

Figure 4. The average migration velocity of the DNA fragments vs. base pair. Other conditions were as in Fig. 2.

the bubble cells with both depths and widths of 190 and $360 \mu \mathrm{m}$, respectively. For small DNA fragments, Table 2 shows that the resolution decreased with increasing the travel length inside the bubble cells, while opposite results for large DNA fragments. This again supported that diffusion and electric field both affected resolution with varying degrees for different sizes of DNA fragments. To clearly show the impact of electric field strength on DNA migration, we plotted their average velocities obtained in three different regions: (1) from the injection point to the point at $2.1 \mathrm{~cm}$, (2) 2.1 to $2.3 \mathrm{~cm}$, and (3) 2.3 to $2.6 \mathrm{~cm}$ against their sizes. Figure 4 apparently shows the order of the migration velocity in regions $1-3$ in the 
Table 2. Resolution values at different detection points

\begin{tabular}{|c|c|c|c|c|c|c|}
\hline \multirow{3}{*}{$\begin{array}{l}\text { Detection } \\
\text { point (mm) }\end{array}$} & \multicolumn{6}{|c|}{ Resolution } \\
\hline & \multicolumn{3}{|c|}{$190 \mu \mathrm{m} \times 190 \mu \mathrm{m}$} & \multicolumn{3}{|c|}{$360 \mu \mathrm{m} \times 360 \mu \mathrm{m}$} \\
\hline & $21^{\text {a) }}$ & $23^{b)}$ & $26^{\mathrm{b})}$ & $21^{\text {a) }}$ & $23^{b)}$ & $26^{\text {b) }}$ \\
\hline \multicolumn{7}{|l|}{ DNA (bp) } \\
\hline $72 / 118$ & 2.1 & 2.1 & 1.8 & 1.8 & 1.5 & 2.3 \\
\hline $118 / 194$ & 8.9 & 6.4 & 6.5 & 4.7 & 4.4 & 6.3 \\
\hline $194 / 234$ & 4.9 & 3.1 & 3.7 & 2.9 & 2.8 & 3.5 \\
\hline 234 / 281 & 4.4 & 2.2 & 3.1 & 2.2 & 2.5 & 3.2 \\
\hline $281 / 271$ & 1.3 & 0.7 & 1.1 & 0.7 & 0.8 & 1.1 \\
\hline $271 / 310$ & 3.6 & 2.0 & 2.6 & 2.4 & 2.3 & 3.2 \\
\hline $310 / 603$ & 13.0 & 8.0 & 11.2 & 8.7 & 9.4 & 17.0 \\
\hline $603 / 872$ & 2.1 & 2.1 & 4.3 & 1.5 & 2.9 & 8.5 \\
\hline $872 / 1078$ & - & 1.2 & 1.6 & 0.6 & 1.3 & 4.2 \\
\hline $1078 / 1353$ & - & - & 0.9 & 0.8 & 1.2 & 3.7 \\
\hline S.W. (min) & $\begin{array}{r}1.37 \sim \\
2.44\end{array}$ & $\begin{array}{r}1.52 \sim \\
3.33\end{array}$ & $\begin{array}{r}2.03 \sim \\
5.31\end{array}$ & $\begin{array}{r}1.32 \sim \\
2.44\end{array}$ & $\begin{array}{r}1.88 \sim \\
6.44\end{array}$ & $\begin{array}{l}2.94 \sim \\
15.34\end{array}$ \\
\hline
\end{tabular}

a) Before the bubble cell

b) Detection point was inside the bubble cell.

presence of the bubble cells is: $1>2>3$, which indicated gradual decreases in the electric field strength inside the bubble cell. Slight variations of the migration velocity in region 1 using the three devices are possibly due to nonuniform distribution of the electric field in the presence of the bubble cell. The migration velocity in the same regions decreased with increasing the size of the bubble cell, supporting the decrease in electric field with increasing the bubble size. The trends of the average velocity $v s$. the base pair with and without the bubble cells are similar, but with higher separation limits (the curve becomes flat at this point) in the presence of the bubble cells. To further support the role of electric field played in improving the resolution for large DNA fragments, we performed the separation of two small anionic fluorophores, SRB and SR101. Table 3 shows that the loss of resolution between these two solutes increased with the traveling distance inside the bubble cells, similar to that observed for the small DNA fragments. The peak width increased as the solutes migrated further inside the bubble cell, indicating that diffusion was the main reason for the loss of resolution. Because the migration velocity for small solutes is proportional to the magnitude of the electric field if the effect of Joule heating is ignored, the change in the velocity inside the bubble cells should provide some information about the distribution of the electric field. The results clearly implied that the electric field strength decreased with increasing the size of the bubble cell and gradually decreased from the entrance of the bubble cell to the exit.

\subsection{Sensitivity}

Owing to a small injection volume, a short optical path length, and highly fluorescent background from plastic substrates, poor concentration sensitivity is problematic and the improvement in sensitivity has been an important issue when using microfluidic devices. To minimize the fluorescent background, a He-Ne laser with $543 \mathrm{~nm}$ output has commonly been used to excite DNA intercalated with $\mathrm{EtBr}$ and the use of plastic substances such as PC and PMMA to make microfluidic devices has been found useful. Table 4 shows up to 17 -fold improvements in the sensitivity when using a device with a bubble cell of $75 \mu \mathrm{m} \times 500 \mu \mathrm{m}$. It is interesting to note that such a device provided greater improvements in the sensitivity, especially for the small DNA fragment (smaller than $310 \mathrm{bp}$ ), than ones with bubble cells of the widths wider than that of the separation channels. This is quite reasonable simply because diffusion in the horizontal direction was small, supported by sharper peak profiles when using the device with a bubble cell of $75 \mu \mathrm{m} \times 500 \mu \mathrm{m}$. However, when a high efficiency is required for the separation of large DNA fragments, a bubble cell of $360 \times 360 \mu \mathrm{m}$ should be favored (Table 2). These results suggested that the geometry of the bubble cell plays a significant role in determining the improvement of sensitivity and resolution. To this end, we should point out that the limits of detection (LODs) for the DNA marker were 0.5 and $0.1 \mu \mathrm{g} / \mathrm{mL}$ on the basis of the peak height for the $72 \mathrm{bp}$

Table 3. Comparison of resolution, peak width, migration time, and velocity of SRB and SR101 at different detection points

\begin{tabular}{|c|c|c|c|c|c|c|c|c|c|c|c|c|c|c|}
\hline & \multicolumn{14}{|c|}{ Width $(\mu \mathrm{m}) \times$ depth $(\mu \mathrm{m})$} \\
\hline & \multicolumn{2}{|c|}{ Resolution } & \multicolumn{4}{|c|}{ Peak width (min) } & \multicolumn{4}{|c|}{ Migration time $(\min )(\mathrm{RSD} \%)^{\mathrm{a})}$} & \multicolumn{4}{|c|}{ Velocity $(\mathrm{cm} / \mathrm{s})$} \\
\hline & \multirow{2}{*}{$\frac{190 \times 190}{\text { SRB/SR101 }}$} & \multirow{2}{*}{$\frac{360 \times 360}{1 \mathrm{SRB} / \mathrm{SR} 101}$} & \multicolumn{2}{|c|}{$190 \times 190$} & \multicolumn{2}{|c|}{$360 \times 360$} & \multicolumn{2}{|l|}{$190 \times 190$} & \multicolumn{2}{|l|}{$360 \times 360$} & \multicolumn{2}{|c|}{$190 \times 190$} & \multicolumn{2}{|c|}{$360 \times 360$} \\
\hline & & & SRB & SR101 & SRB & SR101 & SRB & SR101 & SRB & SR101 & SRB & SR101 & SRB & SR101 \\
\hline $21 \mathrm{~mm}$ & 1.6 & 1.8 & 0.2 & 0.3 & 0.2 & 0.3 & $1.8(1.75)$ & $2.2(1.85)$ & $2.5(1.55)$ & $2.9(1.42)$ & 1.9 & 1.6 & 1.4 & 1.2 \\
\hline $23 \mathrm{~mm}$ & 1.4 & 1.5 & 0.3 & 0.3 & 0.5 & 0.7 & $2.3(2.35)$ & $2.7(1.99)$ & $3.8(2.00)$ & $4.7(1.78)$ & 1.7 & 1.4 & 1.0 & 0.8 \\
\hline $26 \mathrm{~mm}$ & 1.2 & 1.4 & 0.5 & 0.8 & 1.2 & 1.5 & $3.7(2.75)$ & $4.5(2.33)$ & $7.0(1.55)$ & $8.9(1.43)$ & 1.2 & 1.0 & 0.6 & 0.5 \\
\hline
\end{tabular}

a) $n=3$ 
Table 4. Effect of the width and depth of the bubble cell on sensitivity improvement

\begin{tabular}{|c|c|c|c|}
\hline \multirow{2}{*}{$\begin{array}{l}\text { DNA } \\
\text { (bp) }\end{array}$} & \multicolumn{3}{|c|}{ Sensitivity improvement ${ }^{\mathrm{a})}(\mathrm{RSD} \%)^{\mathrm{b})}$} \\
\hline & $\begin{array}{l}190 \mu \mathrm{m} \times \\
190 \mu \mathrm{m}\end{array}$ & $\begin{array}{l}360 \mu \mathrm{m} \times \\
360 \mu \mathrm{m}\end{array}$ & $\begin{array}{l}75 \mu \mathrm{m} \times \\
500 \mu \mathrm{m}\end{array}$ \\
\hline 72 & $2.4(4.25)$ & $3.8(4.00)$ & $13.7(3.85)$ \\
\hline 118 & $2.0(5.21)$ & $5.0(4.95)$ & $13.9(4.86)$ \\
\hline 194 & $1.2(3.25)$ & $4.3(3.15)$ & $14.0(2.95)$ \\
\hline 234 & $1.2(4.60)$ & $4.5(4.40)$ & $15.7(4.00)$ \\
\hline 281 & $0.8(3.70)$ & $4.0(3.50)$ & $13.3(3.10)$ \\
\hline 271 & $1.6(4.95)$ & $4.6(4.70)$ & $17.0(3.85)$ \\
\hline 310 & $2.6(3.00)$ & $4.1(2.95)$ & $14.2(2.73)$ \\
\hline 603 & $3.0(4.11)$ & $5.3(3.56)$ & 11.9 (2.89) \\
\hline 872 & NR.c) & $7.4(2.85)$ & $14.5(2.68)$ \\
\hline 1078 & NR. ${ }^{c)}$ & $7.6(2.77)$ & $11.8(2.50)$ \\
\hline 1353 & NR. ${ }^{c)}$ & $9.2(3.00)$ & $17.7(2.93)$ \\
\hline
\end{tabular}

a) Compared to that using a microfluidic device without a bubble cell

b) $n=3$

c) The last three peaks were not resolved.

fragment when using the microfluidic devices with the bubble cells of $360 \mu \mathrm{m} \times 360 \mu \mathrm{m}$ and $75 \mu \mathrm{m} \times 500 \mu \mathrm{m}$, respectively, which are lower than most reported results [13, 50-53].

\subsection{PCR products}

The analysis of PCR products is of considerable importance in the medical realm and forensics, which has driven greater efforts toward developing electrophoretic separations of DNA in microfluidic channels on plastic substrates because they are low costly and hold potential for disposable analysis tool $[54,55]$. With a sensitivity improvement, the device with a bubble cell of $360 \mu \mathrm{m} \times 360 \mu \mathrm{m}$ was used to analyze the original and diluted (40 times) PCR products after 30 cycles; the results are shown in Fig. 5. The two peaks in each electropherogram correspond to THO1 (191 and 194 bp fragments) that has been one of common primers used in forensics. It is important to point out that the two peaks were not separated and detected in the absence of the bubble cell. When compared to Fig. $5 \mathrm{~A}$, a better resolution is shown in Fig. 5B, mainly because a decrease in the variance of the sample injection when using a small amount of the DNA sample. As mentioned above that the resolution improvement was greater for large DNA fragments, this device should have a high potential for forensics if expanded to four microchannels for high-throughput analysis.

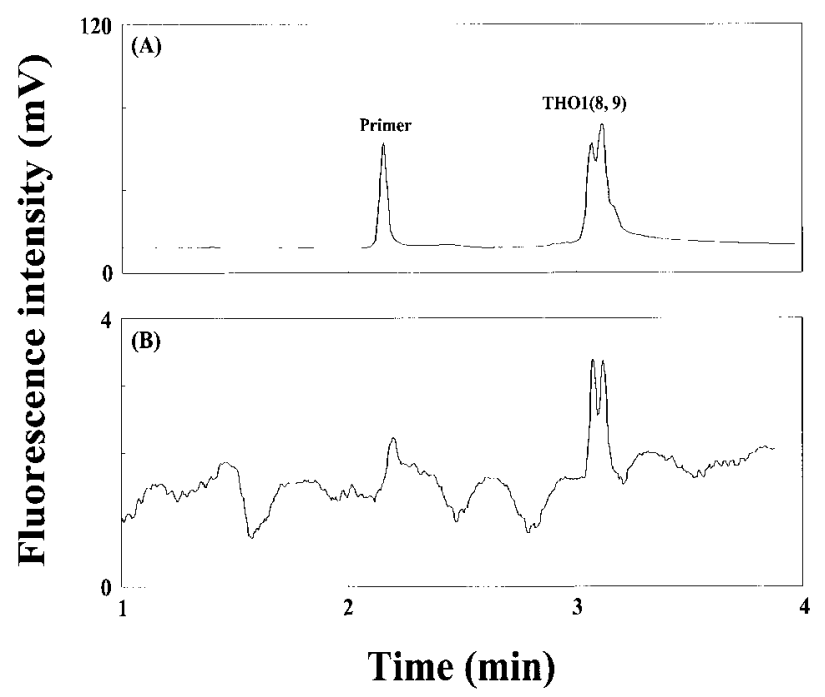

Figure 5. Separation of PCR products (THO1) using a microchannel with a bubble cell of $360 \mu \mathrm{m} \times 360 \mu \mathrm{m}$. Injection of $(A)$ original and $(B)$ diluted (40 times) PCR products after 30 cycles. Other conditions were as in Fig. 2.

\section{Concluding remarks}

Microfluidic channels with bubble cells on PMMA have been made by simple printing methods and tested for DNA separation, with improvements in the sensitivity up to 17-fold. The sensitivity improvement depends on the geometry of the bubble cell that affects diffusion and the distribution of the electric field. In terms of sensitivity, a bubble cell with a width similar to that of the separation channels is suggested. However, a bubble cell with a different depth and width from that of the separation channel is appropriate for the separation of large DNA on the basis of improvements in resolution, mainly due to a greater decrease in the electric field inside the bubble cells. To the best of our knowledge, for the first time, this report shows the improvement in sensitivity and resolution for large DNA fragments without significant loss of resolution for small ones by conducting DNA separation on microfluidic devices with bubble cells. With such features, our efforts will make toward high-throughput DNA analysis using similar devices with a number of microchannels. As shown the geometry of the bubble cell plays a significant role in determining resolution and sensitivity, we should be able to further optimize the conditions for DNA separation and sequencing by fabricating microchannels with different shapes of cells, especially the one with much deeper depths but narrower widths. To achieve this goal, it is extremely important to monitor migration of DNA in the separation channel and bubble cell using a CCD, which is not available in this lab in this stage. This will also allow us to gain more insight of the 
changes in electric field strengths related to the geometry of bubble cells, and the effect of electric field on DNA migration.

This work was supported by the National Science Council of the Republic of China under contract No. NSC 902113-M002-058.

Received February 13, 2002

\section{References}

[1] Venter, J., et al., Science 2001, 291, 1304-1351.

[2] Landers, E. S., et al., Nature 2001, 409, 860-921.

[3] Barta, C., Ronai, Z., Sasvari-Szekely, M., Guttman, A., Electrophoresis 2001, 22, 779-782.

[4] Schulze, A., Downward, J., J. Cell Sci. 2000, 113, 41514156.

[5] Arenkov, P., Kukhtin, A., Gemmell, A., Voloshchuk, S., Chupeeva, V., Mirzabekov, A., Anal. Biochem. 2000, 278, 123131.

[6] Gawron, A. J., Martin, R. S., Lunte, S. M., J. Pharm. Sci. 2001, 14, 1-12.

[7] Lacher, N. A., Garrison, K. E., Martin, R. S., Lunte, S. M., Electrophoresis 2001, 22, 2526-2536.

[8] Bruin, G. J. M., Electrophoresis 2000, 21, 3931-3951.

[9] Dolník, V., Liu, S., Jovanovich, S., Electrophoresis 2000, 21, 41-54.

[10] Carrilho, E., Electrophoresis 2000, 21, 55-65.

[11] Harrison, D. J., Manz, A., Fan, Z., Lüdi, H., Widmer, H. M., Anal. Chem. 1992, 64, 1926-1932.

[12] Ericson, C., Holm, J., Ericson, T., Hjertén, S., Anal. Chem. 2000, 72, 81-87.

[13] Effenhauser, C. S., Bruin, G. J. M., Paulus, A., Ehrat, M., Anal. Chem. 1997, 69, 3451-3457.

[14] Liu, Y., Ganser, D., Schneider, A., Liu, R., Grodzinski, P., Kroutchinina, N., Anal. Chem. 2001, 73, 4196-4201.

[15] Roberts, M. A., Rossier, J. S., Bercier, P., Girault, H., Anal. Chem. 1997, 69, 2035-2042.

[16] Boerner, M., Kohl, M., Pantenburg, F., Bacher, W., Hein, H., Schomburg, W., Microsyst. Technol. 1996, 2, 149-152.

[17] McCormick, R. M., Nelson, R. J., Alonso-Amigo, M. G., Benvegnu, D. J., Hooper, H. H., Anal. Chem. 1997, 69, 26262630.

[18] Woolley, A. T., Hadley, D., Landre, P., deMello, A. J., Mathies, R. A., Northrup, M. A., Anal. Chem. 1996, 68, 4081-4086.

[19] Waters, L. C., Jacobson, S. C., Kroutchinina, N., Khandurina, J., Foote, R. S., Ramsey, J. M., Anal. Chem. 1998, 70, 158-162.

[20] Waters, L. C., Jacobson, S. C., Kroutchinina, N., Khandurina, J., Foote, R. S., Ramsey, J. M., Anal. Chem. 1998, 70, 5172-5176.

[21] Schmalzing, D., Tsao, N., Koutny, L., Chisholm, D., Srivastava, A., Adourian, A., Linton, L., McEwan, P., Matsudaira, P., Ehrlich, D., Genome Res. 1999, 9, 853-858.

[22] Woolley, A. T., Mathies, R. A., Anal. Chem. 1995, 67, 36763680.

[23] Woolley, A. T., Sensabaugh, G. F., Mathies, R. A., Anal. Chem. 1997, 69, 2181-2186.

[24] Backhouse, C., Caamano, M., Oaks, F., Nordman, E., Carrillo, A., Johnson, B., Bay, S., Electrophoresis 2000, 21, 150-156.
[25] Schmalzing, D., Adourian, A., Kounty, L., Ziaugra, L., Matsudaira, P., Ehrlich, D., Anal. Chem. 1998, 70, 2303-2310.

[26] Ronai, Z., Barta, C., Sasvari-Szekely, M., Guttman, A., Electrophoresis 2001, 22, 294-299.

[27] Munro, N. J., Hühmer, A. F. R., Landers, J. P., Anal. Chem. 2001, 73, 1784-1794.

[28] Jacobson, S. C., Ermakov, S. V., Ramsey, J. M., Anal. Chem. 1999, 71, 3273-3276.

[29] Haab, B. B., Mathies, R. A., Anal. Chem 1999, 71, 51375145.

[30] Jacobson, S. C., Hergenröder, R., Koutny, L. B., Warmack, R. J., Ramsey, J. M., Anal. Chem. 1994, 66, 1107-1113.

[31] Culbertson, C. T., Jacobson, S. C., Ramsey, J. M., Anal. Chem. 1998, 70, 3781-3789.

[32] Paegel, B. M., Hutt, L. D., Simpson, P. C., Mathies, R. A. Anal. Chem. 2000, 72, 3030-3037.

[33] Simpson, P. C., Roach, D., Woolley, A. T., Thorsen, T., Johnston, R., Sensabaugh, G. F., Mathies, R. A., Proc. Natl. Acad. Sci. USA 1998, 95, 2256-2261.

[34] Webster, J. R., Burns, M. A., Burke, D. T., Mastrangelo, C. H., Anal. Chem. 2001, 73, 1622-1626.

[35] Huang, Z., Munro, N., Hühmer, A. F. R., Landers, J. P., Anal. Chem. 1999, 71, 5309-5314.

[36] Khandurina, J., Mckinght, T. E., Jacobson, S. C., Waters, L. C. Foote, R. S., Ramsey, J. M., Anal. Chem. 2000, 72, 2995-3000.

[37] Woolley, A. T., Mathies, R. A., Proc. Natl. Acad. Sci. USA 1994, 91, 11348-11352.

[38] Liu, S., Shi, Y., Ja, W. W., Mathies, R. A., Anal. Chem. 1999 $71,566-573$.

[39] Woolley, A. T., Lao, K., Glazer, A. N., Mathies, R. A., Anal. Chem. 1998, 70, 684-688.

[40] Liu, S., Dasgupta, P. K., Anal. Chim. Acta 1993, 283, 747753.

[41] Xue, Y., Yeung, E. S., Anal. Chem. 1994, 66, 3575-3580.

[42] Cole, R. O., Hiller, D. L., Chwojdak, C. A., Sepaniak, M. J., J. Chromatogr. A 1996, 736, 239-245.

[43] Webster, J. R. Burns, M. A. Burke, D. T., Mastrangelo, C. H., J. Capil. Electrophor. Microchip Technol. 1999, 16, 19-25.

[44] Simpson, J. W., Ruiz-Martinez, M. C., Mulhern, G. T., Berka, J., Latimer, D. R., Ball, J. A., Rothberg, J. M., Went, G. T., Electrophoresis 2000, 21, 135-149.

[45] Martynova, L., Locascio L. E., Gaitan, M., Kramer, G. W., Christensen, R. G., MacCrehan, W. A., Anal. Chem. 1997 69, 4783-4789.

[46] Rousseau, J., Drouin, G., Slater, G. W., Electrophoresis 2000, 21, 1464-1470.

[47] Tseng, W.-L., Hsieh, M.-M., Wang, S.-J., Chang, H.-T., J. Chromatogr. A 2000, 894, 219-230.

[48] Tseng, W.-L., Chang, H.-T., Electrophoresis 2001, 22, 763770 .

[49] Huang, M.-F., Hsu, C.-E., Tseng, W.-L., Lin, Y.-C., Chang, H. T., Electrophoresis 2001, 22, 2281-2290.

[50] Chen, Y.-H., Chen, S.-H., Electrophoresis 2000, 21, 165170.

[51] Ogura, M., Agata, Y., Watanabe, K., McCormick, R. M., Hamaguchi, Y., Aso, Y., Mitsuhashi, M., Clin. Chem. 1998, 44, 2249-2255.

[52] Song, L., Fang, D., Kobos, R. K., Pace, S. J., Chu, B., Electrophoresis 1999, 20, 2847-2855.

[53] Duffy, D. C., McDonald, J. C., Schueller, O. J. A., Whitesides, G. M., Anal. Chem. 1998, 70, 4974-4984.

[54] Becker, H., Gärtner, C., Electrophoresis 2000, 21, 12-26.

[55] Soper, S. A., Ford, S. M., Qi, S., McCarley, R. L., Kelley, K., Murphy, M. C., Anal. Chem. 2000, 72, 643A-651A. 